ROCZNIKI NAUK PRAWNYCH

Volume XXVIII, number 2-2018

E n g 1 i s h ver s i o n

DOI: http://dx.doi.org/10.18290/rnp.2018.28.2-4en

JAKUB POKOJ

\author{
ORGANIZATION OF BRANCHES OF THE NATIONAL BANK \\ OF POLAND AFTER WORLD WAR II IN THE SO-CALLED \\ "REGAINED TERRITORIES" AS ILLUSTRATED \\ BY THE BANK'S BRANCH OFFICE IN RACIBÓRZ \\ IN THE YEARS 1945-1947
}

\title{
INTRODUCTORY NOTES
}

The article addresses the issue of organising branches of the National Bank of Poland (Narodowy Bank Polski/NBP) in the so-called "Regained Territories" based on the example of the Racibórz branch of the NBP in the years 1945-1947. So far, this subject area has not been dealt with by the literature. Firstly, the historical and political background of the establishment of the National Bank of Poland will be discussed, in particular the attitude of the Polish communists towards the banking system during World War II will be reviewed. Next, we will look at the establishment of the Bank. Finally, we will review the results of archival research in the State Archives in Katowice, Racibórz Branch, on documents related to the organizational issues of the Racibórz branch of the NBP in the years 1945-1947, that is in the period immediately following the acquisition of the Regained Territories by the Polish administration and the establishment of Polish statehood structures in these areas.

While reviewing the literature on the subject, we need to bear in mind that there are no scientific studies devoted strictly to the organisation of local branches of the National Bank of Poland. As far as the early period of the Bank's operation is concerned, the most valuable study was written by

JAKUB PoKoJ, MA - PhD student at the Chair of Polish Legal History at the Faculty of Law and Administration of the Jagiellonian University, address for correspondence: ul. Gołębia 9, 31-007 Kraków; e-mail: jakub.pokoj@student.uj.edu.pl 
Andrzej Jezierski and Cecylia Leszczyńska, entitled Narodowy Bank Polski 1948-1970. It discusses in depth both the organizational and formal aspects of its functioning. The early years of the Bank's operation are discussed by these authors in Pierwsze lata dziatalności Narodowego Banku Polskiego. Narodziny systemu finansowego PRL. A valuable work presenting the approach of the communists to the idea of the treasury and banking system is Polityka finansowa PKWN lipiec-grudzień 1944, written by Zbigniew Landau.

As a result of the Soviet offensive, launched on June 22, 1944 under the code name "Bagration," the Red Army crossed the Bug River. By virtue of the agreement of the so-called "Big Three," which was hammered out during the peace conference in Tehran (November 28-December 1, 1943), the eastern border of post-war Poland was to run along the Bug, in accordance with the idea of a demarcation line proposed in July 1920 by the British foreign minister, Lord George Curzon. ${ }^{1}$ The Soviet Union, striving to dominate a large part of post-war Central Europe, from the beginning of the war against Hitler's Germany made efforts to organize the core of administration and institutions of the Polish state under its control. However, these goals were difficult to attain due to the fact that a significant number of Polish communist activists, who formed a natural backbone of the pro-Soviet regime, were murdered in the Soviet Union during the period of the so-called "Great Terror" of 1937-1938. ${ }^{2}$

Shortly after the outbreak of the German-Soviet war, a so-called "initiative group" was established in the USSR, consisting of Polish communist activists. They were transported to the territory of occupied Poland, where on January 5, 1942 they established the Polish Workers' Party (Polska Partia Robotniczal PPR). According to the latest research, the action was inspired and supervised by the Soviet headquarters of the communist movement through military intelligence (GRU). ${ }^{3}$ In its second declaration of the series entitled $O$ co walczymy? (November 1943), PPR announced thorough reforms of the banking sector. ${ }^{4}$ This declaration indicated that the planned interim government is "nationalising the large industry which is the key to

\footnotetext{
${ }^{1}$ Cz. Brzoza and A.L. Sowa, Historia Polski 1918-1945 (Kraków: Wydawnictwo Literackie, 2006), 34.

${ }^{2}$ Compare R. PIPES, Komunizm (Warszawa: Świat Książki, 2008), 77.

${ }^{3}$ P. Gontarczy , Polska Partia Robotnicza. Droga do wtadzy 1941-1944 (Warszawa: Fronda PL, 2003), 84.

${ }^{4}$ The slogan encouraging the confiscation of German banks and "socialization" of all other banks appeared already in the first PPR declaration $O$ co walczymy? in March 1943, see Z. LANDAU, "Przeobrażenia aparatu bankowego," in Gospodarka Polski Ludowej 1944-1955, ed. J. Kaliński and Z. Landau (Warszawa: Książka i Wiedza, 1974), 1: 101.
} 
the national economy (steel mills, coal and petroleum mines, arms and machinery industry, large processing industry), banks and transport" (Article 3 para. 7). As presented by the national centre of the communist movement, the banking system was to be nationalised without an exception. We should stress the great importance that PPR attached to the issue of bank nationalisation. Banks were listed as the second key economic sector subject to forced nationalisation. As we have seen above, it was enumerated immediately after the sample catalogue of branches of the so-called "large industry."

The national communist centre, focused around the PPR, was not the only base for the future communist government in Poland. The Polish Committee of National Liberation [Polski Komitet Wyzwolenia Narodowego/PKWN], formed on July 21, 1944 in Moscow, and not in Chełm, ${ }^{6}$ as declared by the propaganda, presented different views with regard to the issue of the banking system from those of the national communist centre. The political agenda of the PKWN was spelt out in its Manifest announced on June 22, $1944 .^{7}$ An extensive passage of the manifesto, located about halfway of its text, immediately after the issues of the occupation administration, that is the so-called "blue police" and the "restoration of democratic freedoms," was devoted to the banking system. Therefore, having regard for the context, and in particular the status of banking demands in relation to other PKWN postulates, it should be said that the issue of the banking system in future Poland was no less important for the Committee than for the PPR.

The manifesto stated that "national property, concentrated today in the hands of the German state and individual German capitalists, in other words large industrial, commercial, banking, transport and forest companies, will now be controlled by the Provisional State Administration. As economic relations become gradually regulated, ownership will be restored." Therefore, unlike the national communist centre, the PKWN did not prejudge ownership issues as regards banks. What is more, the restoration of ownership was to take place at an unspecified time. As it can be deduced from the context, the restoration of private ownership of banking institutions was not ruled out, then. Therefore, in the PKWN's postulates there is no evidence to suggest the possible elimination of private institutions from the banking

\footnotetext{
${ }^{5}$ Deklaracja Programowa PPR „O co walczymy?”, ed. M. Malinowski (Lublin: Wydawnictwo Lubelskie, 1979), 52.

${ }^{6}$ W. Roszkowski, Historia Polski 1914-2004 (Warszawa: Wydawnictwo Naukowe PWN, 2004), 133.

${ }^{7}$ Annex to the Journal of Laws of 1944, No. 1.
} 
system and the establishment of a "superbank," as the National Bank of Poland is currently referred to in the post-war period. ${ }^{8}$

Bearing in mind the divergence of views towards the banking system in post-war Poland, which appeared in the ideological declarations of groups of Polish communists, we need to ask a about the reason for this dichotomy. As it seems, the dissonance was only apparent, and from the very beginning the communists were striving to build a centralised banking system in post-war Poland, following the Soviet model, at the same time breaking with the prewar model, which did not deviate from the models functioning in Western Europe. ${ }^{9}$ It seems that the verbose disparity between the two communist centres resulted only from the desire to ensure the widest possible public support for the PKWN, which could have failed had too radical nationalisation demands been declared. Full nationalisation of the banking system, as proposed by the PPR, can certainly be seen as such. To support this claim, it can be pointed out that a similar discord between the PKWN and the PPR also existed in relation to the nationalisation of the Church's assets, which according to the national centre were to be taken over as part of the agricultural reform, while the Polish communists present in the USSR proposed to exclude church estate from such a reform. ${ }^{10}$ These contradictions were staged and provoked with the goal of concealing the real intentions of the new government. ${ }^{11}$ It can be assumed that the communists acted in a similar way with regard to the banking system. Although the PKWN Manifesto did not mention it, already at the beginning of 1945, when the National Bank of Poland was established, the foundations were laid for a centralized banking system based on the Soviet model with a "superbank" at the forefront.

\section{CREATION OF THE NATIONAL BANK OF POLAND}

At the outset of Poland's communist era, banking was already removed far from its roots, which went back to the time of medieval traders who dealt

\footnotetext{
${ }^{8}$ R. SURA and A. SPRATEK, "Likwidacja Banku Polskiego S.A. i utworzenie Narodowego Banku Polskiego," Roczniki Nauk Prawnych 20, no. 1 (2010): 85.

9 J. BARDACH, B. LEŚNODORSKI, and M. PIETRZAK, Historia ustroju i prawa polskiego (Warszawa: LexisNexis, 2005), 539-40.

${ }^{10}$ W. GóRA, Reforma rolna PKWN (Warszawa: Książka i Wiedza, 1969), 44-56.

${ }^{11}$ Compare J. РокоJ, Wywtaszczenie i nacjonalizacja nieruchomości na tle reform rolnych w Polsce po 1918 roku. Studium prawnohistoryczne (Kraków: Wydawnictwo Uniwersytetu Jagiellońskiego, 2016), 84.
} 
with money exchange. The new issuing institution, as intended by the communist centre, was to be an important tool for influencing the social, political and, above all, the economic situation in post-war Poland. The circumstances surrounding the plan to use the newly created National Bank of Poland to achieve the ultimate goal of the communists, which was a total subordination of Poland and the creation of a Stalinist-style state, are best illustrated by the fact that the creation of the Bank took place without informing Prime Minister Stanisław Mikołajczyk and the authorities of the Bank of Poland S.A. in London about that. ${ }^{12}$ Nevertheless, it should be noted that in the literature on the subject of the communist period it was indicated that the NBP, in the first period of its existence was supposed to replicate "solutions typical for the banking of the pre-war Polish economy,"13 in other words a capitalist economy. However, claims of this kind cannot obscure the fact that the National Bank of Poland was to be used mainly for the purpose of transforming the Polish banking system in line with the Soviet model.

Preparations for the establishment of a new institution of issue had been in progress since the establishment of the PKWN, which already at its inaugural meeting on July 22, 1944 in Moscow addressed the establishment of a bank of issue. ${ }^{14}$ Finally, the National Bank of Poland was established by decree on January $15,1945 .{ }^{15}$ This date marks the beginning of the post-war history of Polish banking, when a new, post-war Polish central bank was established. ${ }^{16}$ The decree in question was issued by the National Council on the basis of the Act of 3 January 1945 on the procedure for issuing legislative decrees. ${ }^{17}$ In accordance with Article 1 the legislative competence of the National Council, provided for in Article 26 para. 1 point 1 of the Act of

\footnotetext{
${ }^{12}$ C. LeszCZyŃska, "Polska bankowość centralna 1828-1989. Bank Polski, Polska Krajowa Kasa Pożyczkowa, Bank Polski SA, Narodowy Bank Polski," in Bankowość Centralna od A do Z, ed. R. Kokoszczyński and B. Pietrzak (Warszawa: Narodowy Bank Polski, Departament Komunikacji Społecznej, 2007), 50.

${ }^{13}$ W. JAWORSKI, "Narodowy Bank Polski 1945-1988 (powstanie-rozwój-przebudowa)," Bank i Kredyt 5-6 (1988): 53.

${ }^{14}$ Z. LANDAu, Polityka finansowa PKWN lipiec-grudzień 1944 (Warszawa: Państwowe Wydawnictwo Ekonomiczne, 1965), 78-79.

${ }^{15}$ Journal of Laws No. 4, item 14 [hereinafter referred to as Decree on the NBP].

${ }^{16}$ The possibility of considering the National Bank of Poland as a successor of the pre-war Bank Polski S.A. is disputed in the source literature. R. Sura and A. Spratek present a broad review of opinions on this subject, which — rightly making reference to the formal, political and historical context—indicate that the post-war NBP was "a completely new institution," SURA and SPrateK, Likwidacja Banku, 87-88. See also J. GliniecKa, J. Harasimowicz, and R. KrasnoDĘBSKI, Polskie Prawo Bankowe (Warszawa: “KiK” Koniczny i Kruszewski, 1996), 20.

${ }^{17}$ Journal of Laws No.1, item 1.
} 
11 September 1944 on the organisation and operation of national councils ${ }^{18}$ was passed down on the newly formed Provisional Government. Therefore, the body issuing the decree on the NBP was the Provisional Government. Incidentally, it can be noted that the Decree on the NBP was the first decree of the Provisional Government on the organisation of a new institution, one might say, from scratch. The Decree on the NBP was a comprehensive regulation, calling a new institution into being represented by the National Bank of Poland. The decree defined its organisational framework and set its tasks. As Zygmunt Karpiński, the Government Plenipotentiary authorised to handle the gold deposit of Bank Polski S.A., pointed out, the decree was drafted in a hurry and many provisions of the pre-war charter of Bank Polski S.A. had been copied. ${ }^{19}$

Pursuant to Article 1 of the Decree on the NBP, the National Bank of Poland was established as a state institution whose aim was to control the circulation of money and loans, with an authorisation to issue banknotes. The NBP had juridical personality (Article 2), and its registered office was each time the seat of the highest authorities of Poland (Article 3). The way the location of the registered seat was provided under Article 3 made it easier to transfer the NBP's registered seat to the capital, be it Łódź or Warsaw, without the need to amend the decree. The vesting of legal personality in the National Bank of Poland laid foundations for the NBP's organisational independence. As a state juridical person, the NBP had then the possibility of establishing its own branches.

Pursuant to Article 5 para. 1 of the decree, the NBP was governed by a council composed of a chairman and ten members, appointed by way of a resolution adopted by the Council of Ministers, at the request of the Minister of the Treasury (Article 6 para.1). The chairman presided over meetings of the council, he was responsible for the execution of its resolutions, and performed general management duties of the National Bank of Poland (Article 9). To technically manage the NBP operations and deal with issues not expressly reserved for the chairman or the council, a management board was appointed (Article 10). The board, composed of a general director and his two deputies was appointed by the Council of Ministers (Article 11 para. 1) upon a motion of the Treasury Minister. The fact that the operation of the National Bank of Poland was supervised by the Treasury Minister (Article

\footnotetext{
${ }^{18}$ Journal of Laws No. 5, item 22.

${ }^{19}$ As cited in A. JEZIERSKI and C. LeSZCZYŃSKA, Bank Polski SA 1924-1951 (Warszawa: Narodowy Bank Polski, 1994), 129.
} 
13 para. 1) and that particular managing officers were appointed by the Council of Ministers upon a request of the Treasury Minister fully subordinated the National Bank of Poland to the executive authority.

From the perspective of the NBP branches, Article 20 para. 1 contain immensely important regulations, as it enumerates the banking operations performed by the NBP, such as: a) discounting bills of exchange and coupons on securities, b) granting loans and opening credits, c) buying and selling interest, municipal and mortgage securities, d) opening of giro accounts and acceptance of deposits, e) buying and selling foreign money, gold, silver and foreign exchange currencies, maintaining accounts abroad and using credits needed to conduct these operations, f) selling remittances and withdrawals to own branches, g) accepting of bills of exchange and other documents for collection, h) accepting deposits for safekeeping and administration, i) processing of all commission orders for banking, and j) the granting of loans against bonds of the State Treasury and guaranteed by the State.

The NBP operations enumerated above were not typical for a standard set of tasks performed by a central bank. ${ }^{20}$ This very wide catalogue of banking operations provided in Article 20 para. 1 illustrated the legislator's desire to concentrate all banking activities in a single bank, ${ }^{21}$ thus organising the NBP on the Soviet pattern. However, this Soviet model was accomplished by the Bank only a result of reforms carried out in the years $1948-1952 .{ }^{22}$ Before 1948, it was an institution which was used-as the literature suggests - for a scope of operations which was wider than the enumerative list of Article 20 para. 1 provided: "The rules of operation and the functions of the central bank should be governed by a charter. [...] its provisions were in no way in line with the actual position and rights of the NBP, which were subject to constant expansion during that period. ${ }^{, 23}$ Except as provided for in Article 22 para. 1, the National Bank of Poland was not entitled to acquire ownership of real estate unless it was intended for the NBP's or its employees' own needs (Article 21). By virtue of Article 44, the provisions of Articles 46-55 of the Charter of Bank Polski S.A. of 2 May 1939 were repealed. ${ }^{24}$

\footnotetext{
${ }^{20}$ Compare J. WęCŁawsKi, System bankowy w Polsce (Rzeszów: Małopolski Instytut Gospodarczy, 2000), 49-50.

${ }^{21}$ G. WóJTowicz, "Narodowy Bank Polski w okresie transformacji," Bank i Kredyt 5-6 (2006): 3.

${ }^{22}$ E. MYŚLAK, "Narodowy Bank Polski wobec transformacji ustrojowej: pozycja prawnaorganizacja -funkcje," Środkowoeuropejskie Studia Polityczne 4 (2013): 136.

${ }^{23}$ A. JEZIERSKI and C. LeSZCZYŃsKA, Narodowy Bank Polski 1948-1970 (Warszawa: Narodowy Bank Polski, 2001), 23.

${ }^{24}$ Journal of Laws No. 46, item 296.
} 


\section{ORGANISATION OF THE RACIBÓRZ BRANCH OF THE NATIONAL BANK OF POLAND}

The organisation of local branches of the National Bank of Poland started throughout the country as early as in 1945. As Cecylia Leszczyńska notes, "the first organisational operations were undertaken in autumn 1944, and direct preparations for the opening of the headquarters and certain branch offices began in 1945., ${ }^{, 25}$ By the end of 1945, 74 NBP branches had been established. $^{26}$ The documentation stored in the State Archive in Katowice, Racibórz Branch of the National Bank of Poland in the first post-war years are of fundamental importance for research on the organization of the Racibórz NBP branch. ${ }^{27}$ Unfortunately, files related to the first post-war years were destroyed ${ }^{28}$ in such a manner that the archives hold only selected documents related to organisational matters in the years 1945-1947. It seems, however, that our archival research did provide enough information and documentation to draw some conclusions on the most important issues related to the organisation of the Raciborz branch of the NBP in the years 1945-1947, including in particular those related to the problems connected with the organisation of the NBP local units in the so-called "Regained Territories."

Racibórz was captured by the Red Army on March 31, 1945. As a result of the wartime operations, the town lay largely in ruins; in the very town centre almost $100 \%$ of the buildings were destroyed. ${ }^{29}$ The general level of destruction in the entire town was around $80-85 \%{ }^{30}$

The Narodowy Bank Polski's branch office was located in a building on the corner of streets Henryka Sienkiewicza 2 and Stanisława Drzymały $32 .{ }^{31}$

\footnotetext{
${ }^{25}$ C. LeszCZyŃSkA, Zarys Historii Polskiej Bankowości Centralnej (Warszawa: Narodowy Bank Polski, Departament Edukacji i Wydawnictw, 2010), 38.

${ }^{26}$ Compare A. JEZIERSKI and C. LeSZCZYŃSKA, Pierwsze lata działalności Narodowego Banku Polskiego. Narodziny systemu finansowego PRL (Warszawa: Narodowy Bank Polski, 1996), 30ff.

${ }^{27}$ State Archives in Katowice, Racibórz Branch, section Instytucje finansowe, title Narodowy Bank Polski Oddziat w Raciborzu, fonds no. 47/0.

${ }^{28}$ The data obtained from the State Archives in Katowice, Racibórz Branch, show that there is no information about the reasons for destruction of files and the key that was adopted to perform thereof.

${ }^{29}$ Racibórz '45: pochodnia Tais, ed. A. Pustelnik (Racibórz: Muzeum w Raciborzu, 1996), 6.

${ }^{30}$ M. Kutzner, Racibórz. (Wrocław-Warszawa-Kraków: Zakład Narodowy im. Ossolińskich, 1965), 36.

${ }^{31}$ At present, the building is located at the same address, as at April 25, 2017. However, it can be supposed that the name of the Stanisława Drzymały street will have been changed by 2 September, 2017, in accordance with Article 6 para. 1 of the Act of 1 April 2016 on the prohibition of propagation of communism or any other totalitarian system through the names of public buildings,
} 
According to the questionnaire submitted to the Administrative Department of the National Bank of Poland, ${ }^{32}$ the building was in a relatively good condition, although it was not completely spared from the war. ${ }^{33}$ The roof, windows, doors, treasury vault, and the doors were destroyed, and the ceilings were seriously damaged. ${ }^{34}$ Due to missing fragments of the glazing and the need to provide the missing glass panes in the cashier room, a sufficient quantity of glass was badly needed, which was achieved by August 1945 at the latest. However, shortly after the delivery of $48.83 \mathrm{~m}^{2}$ of glass, the material was stolen. According to the notification of the head of the Raciborrz NBP Branch submitted on August 30, 1945 by Mr Urbańczyk (an NBP delegate) to the Security Office (Urzad Bezpieczeństwa), the theft was committed by "unknown perpetrators" on the night of 29 August. ${ }^{35}$ However, the questionnaire of October 29, 1945 clearly indicated that " 2 crates of glass [...] were stolen by the military." It is likely that the information about the culprits was deliberately omitted from the notification to the Security Service in order to avoid possible consequences of accusing the military of stealing public property.

The office building of the Raciborz branch of the NBP was still the bone of contention between the NBP and the Tax Office in Racibórz. The entire building at Sienkiewicza 2/Drzymały 32 was initially handed over by the town hall to the Tax Office, which was confirmed orally by the mayor on June 9, 1945, and formally by the Municipal Administrative Office on July $11,1945 .{ }^{36}$ However, before the building was transferred to the Tax Office, it was completely stripped of all the surviving office equipment by the $\mathrm{Mu}$ -

facilities and equipment, Journal of Laws No. 744. As archival media reports indicate, Stanisław Drzymała was a communist activist; accessed April 25, 2017, https://www.nowiny.pl/egazeta /nowiny-raciborskie/2005-03-01/3130-stachu-to-a-nie-michal.html.

32 "The Administrative Department was responsible for the organization of the headquarters and branches. It served as the so-called utility department," A. MiKos, Ustrojowa pozycja banku centralnego w Polsce (Warszawa: Wydawnictwo C.H. Beck, 2006), 66.

33 "Kwestionariusz dot. nieruchomości i ruchomości NBP [Questionnaire concerning movable and immovable property of the NBP]," State Archives in Katowice, Racibórz Branch, section Instytucje finansowe, archival unit 18/47/0/1, Akta dotyczace organizacji Oddziału Banku w Raciborzu; 1945-1946 [further cited as SA Katowice, arch. unit 18/47/0/1].

34 "Opis nieruchomości stanowiącej siedzibę Oddziału" [Description of the immovable property constituting the registered Branch office], in SA Katowice, arch. unit 18/47/0/1.

35 "Zawiadomienie z dnia 30 sierpnia 1945 r. [Notification of August 30, 1945]," SA Katowice, arch. unit 18/47/0/1.

36 "Pismo Naczelnika Urzędu Skarbowego w Raciborzu do Dyrektora Izby Skarbowej w Katowicach z dnia 31 sierpnia 1945 r." [Letter from the Head of the Tax Office in Racibórz to the Director of the Tax Chamber in Katowice dated August 31, 1945], SA Katowice, arch. unit 18/47/0/1. 
nicipal Administrative Office. The dispute arose from the fact that properties belonging to banking institutions were to be transferred to the National Bank of Poland, whereas, naturally, the office buildings of the German tax offices were to become the new Polish tax offices. However, until October 1944 the building in question was occupied by the German Provinzionalbank and later by the Finanzamt, an equivalent of the Polish tax office. The question of ownership could not be clarified as the mortgage books had perished. ${ }^{37}$ As the head of the Racibórz Tax Office, however, declared already in his letter dated August 31, 1945, "now it has come to our attention that the legal owner of this building is precisely the National Bank of Poland as a successor of one of German banks [i.e. Provinzionalbank-J.P.] and then leased it to the German Tax Office." 38 Thus, despite the lack of mortgage books, based mainly on the testimonies of the local residents, it was established that the property at Sienkiewicza 2/Drzymały 32, previously owned by the German bank, was now property of the National Bank of Poland. Incidentally, we can note that the questionnaire also details the stock of movables held by the Racibórz NBP Branch, which looked quite good. Among the numerous pieces of office equipment, one "Urania-Regina" men's bicycle (cat. no. 64) and one automatic rifle (cat. no. 65) were also noted. However, these movables had to be obtained independently by the Racibórz Branch, because in a letter dated December 18, 1945, the Office Head, Mr Urbańczyk, informed the Administrative Department that all office equipment found in the building, as items of the equipment belonging to the German Finanzamt, had been handed over to the Tax Office as its legal successor. ${ }^{39}$

Many of the NBP delegate's efforts were also intended to secure a firm foundation for the maintenance of the Branch's employees and related welfare issues. In two letters dated December 15, 1945, the delegate requested the NBP Administration Department to urgently provide sheepskin coats, winter coats and warm boots ${ }^{40}$ and to provide a residential building to

\footnotetext{
37 "Kwestionariusz dot. nieruchomości i ruchomości NBP [Questionnaire concerning movable and immovable property of the NBP]," SA Katowice, arch. unit 18/47/0/1.

38 "Pismo Naczelnika Urzędu Skarbowego w Raciborzu do Dyrektora Izby Skarbowej w Katowicach z dnia 31 sierpnia 1945 r. [Letter from the Head of the Tax Office in Racibórz to Director of the Tax Chamber in Katowice dated August 31, 1945]," SA Katowice, arch. unit 18/47/0/1.

39 "Pismo Naczelnika Urzędu Skarbowego w Raciborzu do Wydziału Administracyjnego NBP z dnia 18 grudnia 1945 r." [Letter from the Head of the Tax Office in Racibórz to the Administrative Department of the National Bank of Poland dated December 18, 1945], file ref. no. Dz.I.A.269/45, SA Katowice, arch. unit. 18/47/0/1.

40 "Pismo Naczelnika Urzędu Skarbowego w Raciborzu do Wydziału Administracyjnego NBP z dnia 15 grudnia 1945 r." [Letter from the Head of the Tax Office in Racibórz to the Admi-
} 
accommodate the employees to be administered by the Raciborz Branch office. ${ }^{41}$ Although the Headquarters' reply to the letter about the residential building has not been preserved, it must have been received shortly because on December 18, 1945, Urbańczyk provided the Administrative Department with additional explanations concerning the building occupied by the employees of the Branch for housing purposes. ${ }^{42}$

Apart from accommodation and welfare issues, the important element of the organizational activity of the NBP Branch in Racibórz was the takeover of management of the equipment of the German banks, in particular the real estate belonging to German banks. The stock of the Racibórz branch of the National Bank of Poland in the second half of 1946 was described in detail in a report dated December 10, 1946 by Walerian Kafliński, the administrator of the abandoned and former German credit institutions in the Racibórz district: "The Racibórz district of the National Bank of Poland comprises the 4 powiats of Głąbczce [Głubczyce - J.P.], Kozielsk, Racibórz and Rybnik. The first three are located in the Regained Territories, all districts suffered greatly from the war and the town was burnt down in $80 \%$ on average. The work of the district administrator [...] was to establish the ownership of the abandoned and former German credit institutions within the bank district. In general, it was found that there were merely a handful buildings [...] in a satisfactory condition or those requiring some repairs." ${ }^{, 3}$ The list attached to the report mentions 15 plots with buildings owned by German banking institutions, of which 11 were described as "burnt down," 3 as partially destroyed $(65 \%, 30 \%$ and $20 \%$ of damage, respectively) and only one was in a good condition.

nistrative Department of the National Bank of Poland dated December 18, 1945], file ref. no. Dz.I.A.250/45, SA Katowice, arch. unit 18/47/0/1.

41 "Pismo Naczelnika Urzędu Skarbowego w Raciborzu do Wydziału Administracyjnego NBP z dnia 15 grudnia 1945 r." [Letter from the Head of the Tax Office in Racibórz to the Administrative Department of the National Bank of Poland dated December 18, 1945], file ref. no. Dz.I.A.251/45, SA Katowice, arch. unit 18/47/0/1.

42 "Pismo Naczelnika Urzędu Skarbowego w Raciborzu do Wydziału Administracyjnego NBP z dnia 18 grudnia 1945 r." [Letter from the Head of the Tax Office in Racibórz to the Administrative Department of the National Bank of Poland dated December 18, 1945], file ref. no. Dz.I.A.268/45, SA Katowice, arch. unit 18/47/0/1.

43 "Sprawozdanie z działalności w mieś. VII, VIII, IX, X, I XI. 1946 r." [Report on activities in months VII, VIII, IX, X and XI 1946], The State Archives in Katowice, Racibórz Branch, Zarzadca mieniem opuszczonym Narodowy Bank Polski. Sprawozdania kasowe i opisowe 1946-1947 [The administration of the deserted property by the National Bank of Poland. Cashier and descriptive reports 1946-1947], arch. unit 18/47/0/197 [further cited as SA Katowice, arch. unit 18/47/0/197]. 
Individual properties were administered by communes (gminas). Therefore, the administrator of abandoned and former German property, Mr Kafliński, made efforts to take over those properties belonging to the National Bank of Poland which had not yet been handed over to the NBP administration. ${ }^{44}$ In the months that followed, the activity of the administrator in the Racibórz bank district was limited to further efforts to take over the management of buildings belonging to German banking institutions, or to conclude lease or lease agreements for properties belonging to the National Bank of Poland. ${ }^{45}$

\section{CONCLUSION}

The activity of the Racibórz Branch of the National Bank of Poland in the years 1945-1947 was part of the role intended for this institution by the Polish legislator. As we mentioned before, the National Bank of Poland under the Decree on the NBP was to play the role of a specific "superbank." This intent of the communist legislator was declared, albeit somewhat vaguely, already in the declaration $O$ co walczymy? by the PPR of November 1943. It explicitly indicated that banks would be nationalised. The National Bank of Poland, built from scratch from February 1945, was conceived as a dominant institution in the Polish banking system, combining the roles of a central bank and an institution providing standard banking services.

The unique omnipotence of the National Bank of Poland was, as it seems, most fully visible in the so-called "Regained Territories," where the Polish authorities could build a banking system from scratch in a completely unrestricted manner. In the light of our considerations so far, this seems also to have been the case with the Racibórz bank district. The NBP Branch operating there took over all property belonging to German banking institutions. Apparently, the condition of this estate depended on the intensity of the war operations in a particular area. Due to the fact that the fighting in the areas subject to the Racibórz branch of the NBP was relatively fierce, the local NBP possessions with regard to German banking institutions was miserable.

44 “Sprawozdanie z działalności za m-c grudzien 1946 r." [Report on the activities of December 1946], SA Katowice, arch. unit 18/47/0/97.

45 "Sprawozdanie z działalności w mies. styczniu i lutym 1947 r." [Report on the activities of January and February 1947], SA Katowice, arch. unit 18/47/0/197; "Sprawozdanie z działalności w miesiącu marcu 1947 r." [Report on the activities of March 1947], SA Katowice, arch. unit 18/47/0/197. 
The state of affairs in the Racibórz branch office also demonstrates the validity of the view presented in the literature that there is a close correlation between relations in the State and the situation of its central bank. ${ }^{46}$

The organization of NBP branches in the Regained Territories, as shown by the example of Racibórz, encountered various, often quite trivial, problems. In the case of war-stricken areas, such as all 4 powiats under the jurisdiction of the Racibórz Branch, the first challenge was to ensure decent housing conditions for the Bank's daily operation. Notwithstanding the necessity to enable the Branch to function normally, its leadership also had to make efforts to address the most basic needs of its employees, such as accommodation or warm clothing. However, the situation of the Racibórz branch of the National Bank of Poland was not hopeless. According to the preserved archives, the office equipment, building materials and clothing were delivered relatively quickly, despite the fact that even the seemingly most trivial matters related to provisions and materials were handled by the Administrative Department of the NBP head office in Łódź. This situation can demonstrate that the communist authorities attached great importance to the organization of local branch offices of Narodowy Bank Polski.

\section{BIBLIOGRAPHY}

SOURCES OF LAW

Dekret z dnia 15 stycznia 1945 r. o Narodowym Banku Polskim [Decree of 15 October 1945 on the National Bank of Poland]. Journal of Laws No. 4, item 14.

Manifest Polskiego Komitetu Wyzwolenia Narodowego ogłoszony dnia 22 lipca 1944 roku [Manifesto of the Polish Committee of National Liberation announced on 22 July 1944]. Annex to the Journal of Laws No. 1.

Obwieszczenie Ministra Skarbu z dnia 2 maja 1939 r. o ogłoszeniu jednolitego tekstu statutu Banku Polskiego [Announcement of the Minister of the Treasury of 2 May 1939 on the announcement of the consolidated text of the Charter of Bank Polski]. Journal Laws No. 46, item 296.

Ustawa z dnia 11 września 1944 r. o organizacji i zakresie działania rad narodowych [Act of 11 September 1944 on the organisation and scope of activities of national councils], Journal of Laws No. 5, item 22.

Ustawa z dnia 3 stycznia 1945 r. o trybie wydawania dekretów z mocą ustawy [Act of 3 January 1945 on the procedure for issuing decree-laws], Journal of Laws No. 1, item 1.

Ustawa z dnia 1 kwietnia 2016 r. o zakazie propagowania komunizmu lub innego ustroju totalitarnego przez nazwy budowli, obiektów i urządzeń użyteczności publicznej [Act of 1 April 2016

\footnotetext{
${ }^{46}$ R.W. KASZUBSKI, "Ewolucja polskiej bankowości centralnej. Aspekty prawne,” Materiaty i Studia 44 (1994): 5.
} 
on the prohibition of propagation of communism or any other totalitarian system through the names of public buildings, facilities and equipment]. Journal of Laws, item 744.

\section{ARCHIVAL SOURCES}

State Archives IN Katowice, Racibórz Branch, section Instytucje finansowe, arch. unit 18/47/0/1, Akta dotyczace organizacji Oddziału Banku w Raciborzu; 1945-1946 [Files related to the organisation of the Bank Branch in Racibórz; 1945-1946].

StATE ARchives IN KATOwice, Racibórz Branch, section Instytucje finansowe, arch. unit 18/47/0/197, Zarzadca mieniem opuszczonym Narodowy Bank Polski. Sprawozdania kasowe i opisowe 1946-1947 [The administration of deserted property by the National Bank of Poland. Cashier and descriptive reports 1946-1947].

\section{Published SOURCES}

PPR's programme declaration $O$ co walczymy?, edited by Marian Malinowski. Lublin: Wydawnictwo Lubelskie, 1979.

\section{LITERATURE}

BARDACH, Juliusz, Bogusław LeŚNOdORSKI, and Michał PIETRZAK. Historia ustroju i prawa polskiego. Warszawa: LexisNexis, 2005.

BrzozA, Czesław, and Andrzej L. Sowa. Historia Polski 1918-1945. Kraków: Wydawnictwo Literackie, 2006.

Gliniecka, Jolanta, Jerzy Harasimowicz, and Robert KrasnodębSki. Polskie Prawo Bankowe. Warszawa: „KiK” Koniczny i Kruszewski, 1996.

GontarczyK, Piotr. Polska Partia Robotnicza. Droga do wtadzy 1941-1944. Warszawa: Fronda PL, 2003.

GóRA, Władysław. Reforma rolna PKWN. Warszawa: Książka i Wiedza, 1969.

JAWORSKI, Władysław. "Narodowy Bank Polski 1945-1988 (powstanie-rozwój-przebudowa).” Bank i Kredyt 5-6 (1988): 97-136.

JeZIERski, Andrzej, and Cecylia LeszczyńsKa. Historia Polski 1924-1951. Warszawa: Narodowy Bank Polski, 1994.

JeZierski, Andrzej, and Cecylia LeszczyńsKa. Narodowy Bank Polski 1948-1970. Warszawa: Narodowy Bank Polski, 2001.

JeZIerski, Andrzej, and Cecylia Leszczyńska. Pierwsze lata działalności Narodowego Banku Polskiego. Narodziny systemu finansowego PRL. Warszawa: Narodowy Bank Polski, 1996.

KASZUBSKI, Remigiusz W. "Ewolucja polskiej bankowości centralnej. Aspekty prawne." Materiaty i Studia 44 (1994), throughout.

KuTZNER Marian. Racibórz. Wrocław-Warszawa-Kraków: Zakład Narodowy im. Ossolińskich, 1965.

LANDAU, Zbigniew. Polityka finansowa PKWN lipiec-grudzień 1944. Warszawa: Państwowe Wydawnictwo Ekonomiczne, 1965.

LANDAU, Zbigniew. "Przeobrażenia aparatu bankowego.” In Gospodarka Polski Ludowej 19441955, edited by Janusz Kaliński and Zbigniew Landau, 1: 100-28. Warszawa: Książka i Wiedza, 1974. 
LESZCZYŃSKA, Cecylia. "Polska bankowość centralna 1828-1989. Bank Polski, Polska Krajowa Kasa Pożyczkowa, Bank Polski SA, Narodowy Bank Polski.” In Bankowość Centralna od A do Z, edited by Ryszard Kokoszczyński and Bogusław Pietrzak, 27-64. Warszawa: Narodowy Bank Polski, Departament Komunikacji Społecznej, 2007.

LeszCZyńska, Cecylia. Zarys Historii Polskiej Bankowości Centralnej. Warszawa: Narodowy Bank Polski, Departament Edukacji i Wydawnictw, 2010.

Mıкоs, Agnieszka. Ustrojowa pozycja banku centralnego w Polsce. Warszawa: Wydawnictwo C.H. Beck, 2006.

PIPES, Richard. Komunizm. Translated by Jerzy Jan Górski. Warszawa: Świat Książki, 2008.

PокоJ, Jakub. Wywtaszczenie i nacjonalizacja nieruchomości na tle reform rolnych w Polsce po 1918 roku. Studium prawnohistoryczne. Kraków: Wydawnictwo Uniwersytetu Jagiellońskiego, 2016.

Racibórz '45: pochodnia Tais. Edited by Andrzej Pustelnik. Racibórz: Muzeum w Raciborzu, 1996. RoszKowski, Wojciech. Historia Polski 1914-2004. Warszawa: Wydawnictwo Naukowe PWN, 2004. SurA, Rafał and Andrzej SPRATEK. "Likwidacja Banku Polskiego S.A. i utworzenie Narodowego Banku Polskiego." Roczniki Nauk Prawnych 20, no. 1 (2010): 79-89.

WĘCŁAWSKI, Jerzy. System bankowy w Polsce. Rzeszów: Małopolski Instytut Gospodarczy, 2000.

\author{
ORGANIZATION OF BRANCHES OF THE NATIONAL BANK OF POLAND \\ AFTER WORLD WAR II IN THE SO-CALLED "REGAINED TERRITORIES" \\ AS ILLUSTRATED BY THE BANK'S BRANCH OFFICE IN RACIBÓRZ \\ IN THE YEARS 1945-1947
}

\title{
Summary
}

The aim of this paper is to analyse the issues regarding the process of organising branches of Narodowy Bank Polski in the so-called "Regained Territories" based on the example of the National Bank of Poland's branch office in Racibórz. First, the communist authorities' attitude towards the banking system was discussed. Secondly, the legislation in the field of banking was analysed, especially the Decree on the National Bank of Poland of 15 January 1945. Then, the archival sources regarding the Racibórz branch of NBP were analysed. The final part of the article was devoted to conclusions based on the research.

Key words: National Bank of Poland; Racibórz; Regained Territories.

Translated by Tomasz Patkowski

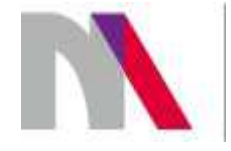

The preparation of the English version of Roczniki Nauk Prawnych (Annals of Iuridical Sciences) and its publication in electronic databases was financed under contract no. 836/PDUN/2018 from the resources of the Minister of Science and Higher Education for the popularization of science. 